\title{
ESSENTIAL NORM OF WEIGHTED COMPOSITION OPERATORS BETWEEN BLOCH-TYPE SPACES IN THE OPEN UNIT BALL
}

\author{
JuntaO DU AND XiAngling ZHU
}

Abstract. In this paper, we give an estimation for the essential norm of weighted composition operators between Bloch-type spaces in the open unit ball of $\mathbb{C}^{n}$.

Mathematics subject classification (2010): 47B33, 30H30.

Keywords and phrases: Bloch-type spaces, essential norm, weighted composition operator.

\section{REFERENCES}

[1] B. Choe, H. Koo And W. Smith, Composition operators on small spaces, Integr. Equ. Oper. Theory 56 (2006), 357-380.

[2] D. Clahane And S. STEVić, Norm equivalence and composition operators between Bloch/Lipschitz spaces of the unit ball, J. Ineq. Appl. Vol. 2006, Article ID 61018, (2006), 11 pages.

[3] F. ColonnA, New criteria for boundedness and compactness of weighted composition operators mapping into the Bloch space, Cent. Eur. J. Math. 11 (2013), 55-73.

[4] C. Cowen And B. MacCluer, Composition Operators on Spaces of Analytic Functions, CRC Press, Boca Raton, FL, 1995.

[5] J. DU AND S. LI, Weighted composition operators from Zygmund type spaces into Bloch type spaces, Math. Ineq. Appl. 20 (2017), 247-262.

[6] J. DU, S. LI AND Y. ZHANG, Essential norm of generalized composition operators on Zygmund type spaces and Bloch type spaces, Ann. Polon. Math. 119 (2017), 107-119.

[7] J. DU, S. Li AND Y. Zhang, Essential norm of weighted composition operators on Zygmund-type spaces with normal weight, Math. Ineq. Appl. 21 (2018), 701-714.

[8] S. FANG AND Z. ZHOU, New characterizations of composition operators between Bloch type spaces in the unit ball, Bull. Korean Math. Soc. 52 (2015), 751-759.

[9] O. HYVÄRINEN AND M. LINDSTRÖM, Estimates of essential norm of weighted composition operators between Bloch-type spaces, J. Math. Anal. Appl. 393 (2012), 38-44.

[10] S. Krantz And S. STević, On the iterated logarithmic Bloch space on the unit ball, Nonlinear Anal. TMA 71 (2009), 1772-1795.

[11] S. Li AND S. STEVIĆ, Weighted composition operators from $H^{\infty}$ to the Bloch spaces on the polydisc, Abstr. Appl. Anal. Vol. 2007, Article ID 48478, (2007), 12 pages.

[12] S. Li AND S. STEVIĆ, Weighted composition operators from Bergman-type spaces into Bloch spaces, Proc. Indian Acad. Sci. Math. Sci. 117 (2007), 371-385.

[13] S. Li AND S. STEvić, Generalized composition operators on Zygmund spaces and Bloch type spaces, J. Math. Anal. Appl. 338 (2008), 1282-1295.

[14] S. Li AND S. STEVIĆ, Weighted composition operators between $H^{\infty}$ and $\alpha$-Bloch spaces in the unit ball, Taiwanese J. Math. 12 (2008), 1625-1639.

[15] S. Li And S. STEVIĆ, Weighted composition operators from Zygmund spaces into Bloch spaces, Appl. Math. Comput. 206 (2008), 825-831.

[16] S. Li And S. Stević, Composition followed by differentiation between $H^{\infty}$ and $\alpha$-Bloch spaces, Houston J. Math. 35 (2009), 327-340.

[17] S. Li AND S. STEVIĆ, Integral-type operators from Bloch-type spaces to Zygmund-type spaces, Appl. Math. Comput. 215 (2009), 464-473. 
[18] S. Li And S. STEVIĆ, Products of integral-type operators and composition operators between Blochtype spaces, J. Math. Anal. Appl. 349 (2009), 596-610.

[19] S. Li AND S. STEVIĆ, On an integral-type operator from $\omega$-Bloch spaces to $\mu$-Zygmund spaces, Appl. Math. Comput. 215 (2010), 4385-4391.

[20] S. LI AND S. STEVIĆ, Products of composition and differentiation operators from Zygmund spaces to Bloch spaces and Bers spaces, Appl. Math. Comput. 217 (2010), 3144-3154.

[21] B. MACCluer AND R. ZHAO, Essential norm of weighted composition operators between Blochtype spaces, Rocky. Mountain J. Math. 33 (2003), 1437-1458.

[22] K. Madigan And A. Matheson, Compact composition operators on the Bloch space, Trans. Amer. Math. Soc. 347 (1995), 2679-2687.

[23] S. Ohno, K. Stroethoff And R. Zhao, Weighted composition operators between Bloch-type spaces, Rocky Mountain J. Math. 33 (2003), 191-215.

[24] J. SHI AND L. LuO, Composition operators on the Bloch spaces of several complex variables, Acta Math. Sin. (Engl. Ser.) 16 (2000), 85-98.

[25] A. ShieldS AND D. Williams, Bounded projections, duality, and multipliers in spaces of analytic functions, Trans. Amer. Math. Soc. 162 (1971), 287-302.

[26] S. STEVIĆ, Essential norms of weighted composition operators from the $\alpha$-Bloch space to a weightedtype space on the unit ball, Abstr. Appl. Anal. Vol. 2008, Article ID 279691, (2008), 11 pages.

[27] S. STEVIĆ, On a new integral-type operator from the weighted Bergman space to the Bloch-type space on the unit ball, Discrete Dyn. Nat. Soc. Vol. 2008, Article ID 154263, (2008), 14 pages.

[28] S. STEVIĆ, Norm and essential norm of composition followed by differentiation from $\alpha$-Bloch spaces to $H_{\mu}^{\infty}$, Appl. Math. Comput. 207 (2009), 225-229.

[29] S. STEVIĆ, On a new integral-type operator from the Bloch space to Bloch-type spaces on the unit ball, J. Math. Anal. Appl. 354 (2009), 426-434.

[30] S. STEVIĆ, On an integral-type operator from logarithmic Bloch-type and mixed-norm spaces to Bloch-type spaces, Nonlinear Anal. TMA 71 (2009), 6323-6342.

[31] S. STEVIĆ, On an integral operator between Bloch-type spaces on the unit ball, Bull. Sci. Math. 134 (2010), 329-339.

[32] S. Stević, R. Chen AND Z. Zhou, Weighted composition operators between Bloch type spaces in the polydisc, Sb. Math. 201 (1-2) (2010), 289-319.

[33] X. TANG, Extended Cesàro operators between Bloch-type spaces in the unit ball of $\mathbb{C}^{n}, \mathrm{~J}$. Math. Anal. Appl. 326 (2007), 1199-1211.

[34] R. Timoney, Bloch function in several complex variables, I, Bull. London Math. Soc. 12 (1980), 241-267.

[35] M. TJAnI, Compact composition operators on some Möbius invariant Banach spaces, $\mathrm{PhD}$ dissertation, Michigan State University, 1996.

[36] X. Zhang, Composition type operator from Bergman space to $\mu$-Bloch type space in $\mathbb{C}^{n}$, J. Math. Anal. Appl. 298 (2004), 710-721.

[37] X. Zhang AND J. LI, Weighted composition operators between $\mu$-Bloch spaces on the unit ball of $\mathbb{C}^{n}$, Acta Math. Sci. Ser. A 29 (2009), 573-583.

[38] X. ZhANG AND J. XiaO, Weighted composition operators between $\mu$-Bloch spaces on the unit ball, Sci. China, Ser. A 48 (2005), 1349-1368.

[39] Z. Zhou AND H. Zeng, Composition operators between $p$-Bloch space and $q$-Bloch space in the unit ball, Progr. Natur. Sci. 13 (2003), 233-236.

[40] K. ZHU, Spaces of Holomorphic Functions in the Unit Ball, Springer-Verlag, New York, 2004.

[41] X. ZHU, Generalized weighted composition operators on Bloch-type spaces, J. Ineq. Appl. 2015 (2015), 59-68.

[42] X. ZHU, Essential norm of generalized weighted composition operators on Bloch-type spaces, Appl. Math. Comput. 274 (2016), 133-142. 